\title{
Flutuação das variáveis séricas em cabras e estudo comparativo da absorção de anticorpos em cabritos recém-nascidos utilizando colostro bovino e caprino ${ }^{1}$
}

\author{
Anali Linhares Lima ${ }^{2}$, Patricia Pauletti², Ivanete Susin ${ }^{3}$, Raul Machado-Neto \\ ${ }^{2}$ Laboratório de Anatomia e Fisiologia Animal, Departamento de Zootecnia, Escola Superior de Agricultura "Luiz de Queiroz", Universidade \\ ${ }^{3}$ Departamento de Zootecnia, Escola Superior de Agricultura "Luiz de Queiroz", Universidade de São Paulo ESALQ/USP.
}

${ }^{1}$ Trabalho financiado pela FAPESP. de São Paulo ESALQ/USP

RESUMO - Objetivou-se determinar a flutuação no nível de anticorpos séricos em cabras nos períodos pré e pós-parto e a eficiência do processo de aquisição de imunidade passiva em cabritos recém-nascidos utilizando colostros bovino e caprino, visando à avaliação de uma alternativa de manejo de colostro. Foram utilizadas 18 cabras e suas respectivas crias, num total de 33 animais. A coleta de sangue das cabras foi iniciada 45 dias antes da data prevista para o parto e foi realizada em intervalos de cinco dias até o 5o dia após o parto. Os cabritos foram distribuídos em dois grupos: um grupo recebeu colostro caprino e o outro colostro bovino. As coletas de sangue foram feitas às $0,12,24$ e 48 horas e aos 5, 10, 15, 17, 20, 25, 30, 35, 40, 50 e 60 dias de vida. Foram analisadas as concentrações séricas de proteína total e imunoglobulinas, além da concentração de imunoglobinas no colostro. O delineamento experimental foi o inteiramente casualizado e as variáveis séricas analisadas como medidas repetidas. A ausência de queda na concentração sérica de proteínas totais e imunoglobinas no período pré-parto indica que a mobilização de anticorpos para glândula mamária ocorre em concentrações que permitem o animal manter essas variáveis sem grandes alterações. No grupo que recebeu colostro bovino, a data de concentração máxima de proteínas totais $(7,16 \pm 0,28$ g/dL) foi verificada às 48,68 \pm 0,70 horas de vida e a de imunoglobinas, às 48,75 \pm 0,73 horas, com média de 37,56 $\pm 2,38$ unidades ZST (turvação por sulfato de zinco). No grupo que recebeu colostro caprino, os valores máximos de proteínas totais e imunoglobinas séricas ocorreram mais tardiamente, aos 20,05 \pm 1,36 e 20,11 \pm 1,72 dias de vida, com médias de 5,91 $\pm 0,22 \mathrm{~g} / \mathrm{dL}$ e $28,17 \pm 2,05$ unidades ZST, respectivamente. O colostro caprino pode ser substituído pelo colostro bovino, que promove melhor aquisição inicial de imunoglobulinas aos neonatos.

Palavras-chave: imunoglobulinas, pequenos ruminantes, proteína sérica, Saanen

\section{Fluctuation of serum variables in goats and comparative study of antibody absorption in new-born kids using cattle and goat colostrum}

\begin{abstract}
The objective of this study was to determine the fluctuation of serum antibodies in goats in the period before and immediately after kidding and the passive immunity acquisition efficiency in kids fed bovine and goat colostrum, to assess an alternative for colostrum management. Eighteen goats and their offspring were used in a total of 33 animals. Goat blood samples started to be collected 45 days before the predicated kidding date, at five-day intervals until the $5^{\text {th }}$ day post kidding. The kids were distributed in two groups: one group received goat colostrum and the other cattle colostrums. Blood collections were made $0,12,24$ and 48 hours, and at 5, 10, 15, 17, 20, 25, 30, 40, 50 and 60 days of age. The serum concentration of total protein (TP) and immunoglobulins (Ig), and the colostrum IgG concentration were analyzed. A randomized complete design was used and the serum variables were analyzed as repeated measurements. The absence of fall in TP and Ig serum concentration in the pre partum period, indicated that the mobilization of serum antibodies to mammary gland occurred in concentrations that allow the animals to keep these variables without great alterations. In the group that received cattle colostrum, the highest concentration data for TP was observed at $48.68 \pm 0.79$ hours after birth, with mean of $7.16 \pm 0.28 \mathrm{~g} / \mathrm{dL}$, and the highest concentration date for Ig at $48 \pm 0.73$, with mean of $37.56 \pm 2.38$ ZST units (zinc sulfate turbidity). In the group that received goat colostrum, the maximum values for serum TP and Ig occurred later, at $20.05 \pm 1.36$ and $20.11 \pm 1.72$ days after birth, with means of $5.91 \pm 0.22 \mathrm{~g} / \mathrm{dL}$ and $28.17 \pm 2.05$ ZST units (zinc sulphate turbidity), respectively. Goat colostrum can be substituted by cattle colostrums, that promotes better initial immunoglobulin acquisition by the neonates.
\end{abstract}

Key Words: immunoglobulin, Saanen, serum protein, small ruminant 


\section{Introdução}

A maneira pela qual os anticorpos maternos são transferidos para o recém-nascido depende do tipo de barreira placentária. A placenta sindesmocorial dos ruminantes, que apresenta cinco membranas entre a circulação materna e a fetal, impede a passagem de anticorpos entre as duas circulações. Esses animais nascem com níveis insignificantes de imunoglobulinas no soro e necessitam do aporte de colostro rico em anticorpos logo após o nascimento para aquisição de proteção inicial eficiente.

O colostro em caprinos, assim como nos demais ruminantes, é rico em IgG, IgA e IgM e IgG é a principal classe de imunoglobulinas presente nas primeiras secreções lácteas (Halliday, 1978). Segundo Santos et al. (1994), a concentração de IgG no colostro caprino varia de 69,3 a 217,8 mg/mL na primeira secreção e reduz aproximadamente $50 \%$ nas primeiras 12 horas.

As contraindicações para o consumo de colostro e leite caprino estão relacionadas à transmissão de doenças infectocontagiosas, como a artrite encefalite caprina a vírus (CAEV) para as crias. Essa infecção é causada por lentivírus e caracteriza-se clinicamente por poliartrite em caprinos adultos e por leucoencefalomielite em crias (Cork et al., 1974; Crawford \& Adams, 1981).

Como a principal via de transmissão do vírus causador do CAE são as secreções lácteas de mães infectadas, têm-se desenvolvido maneiras para reduzir ou anular o contato do recém-nascido com essas secreções. O estabelecimento de um banco de colostro de vacas é recomendável, pois constitui-se fonte rica de IgG e livre do vírus (Argüello et al., 2003).

Objetivou-se determinar a flutuação dos níveis séricos de anticorpos em cabras nos períodos pré e pósparto e a eficiência do processo aquisição de imunidade passiva em cabritos recém-nascidos utilizando colostros bovino e caprino para avaliação de uma alternativa de manejo de colostro e melhor conhecimento do processo de formação e transferência de imunidade passiva.

\section{Material e Métodos}

A parte experimental de campo foi realizada nas instalações do Sistema de Produção Intensiva de Caprinos e Ovinos (SIPOC) do Departamento de Zootecnia da Escola Superior de Agricultura “Luiz de Queiroz”, município de Piracicaba, São Paulo. As análises laboratoriais também foram realizadas no Laboratório de Anatomia e Fisiologia Animal (LAFA) do Departamento de Zootecnia.
O colostro bovino foi obtido com a colaboração do Clube de Práticas Zootécnicas do Departamento de Zootecnia da ESALQ/USP (CPZ) e o colostro caprino, no Sistema de Produção Intensiva de Caprinos e Ovinos (SIPOC). O colostro bovino foi homogeneizado para formação de pools e a concentração de imunoglobulinas foi estimada com o auxílio de colostrômetro (Fleenor \& Sttot, 1980), hidrômetro modificado que relaciona a concentração de imunoglobulinas do colostro de vacas com sua gravidade específica. Os pools foram subdivididos em frascos de $250 \mathrm{~mL}$, identificados e armazenados a $-20^{\circ} \mathrm{C}$.

O colostro caprino recebido foi homogeneizado para formação dos pools e transferido para frascos de $250 \mathrm{~mL}$, identificados e armazenados a $-20^{\circ} \mathrm{C}$.

Foram utilizadas 18 cabras da raça Saanen e seus respectivos cabritos. As cabras foram mantidas em baias coletivas com bebedouro e cocho para silagem e a ração oferecida durante o período experimental foi formulada para atender às necessidades de cabras no período préparto (Tabela 1).

Os 33 cabritos utilizados, 19 fêmeas e 14 machos, foram separados de suas mães após o nascimento e distribuídos ao acaso em dois grupos, de modo que um recebeu colostro caprino e o outro colostro bovino. O volume fornecido foi de $5 \%$ do peso vivo dos animais, às 0, 12, 24 e 36 horas de vida. A partir de 48 horas de vida, todos os animais receberam $400 \mathrm{~mL}$ de leite bovino no balde, duas vezes ao dia, até o desaleitamento, aos 60 dias de vida.

Durante os primeiros 20 dias de vida, os animais foram alojados em gaiolas individuais, com assoalho ripado, baldes para concentrado e água à vontade. Após este período, foram transferidos para baias coletivas, com bebedouro e cocho para concentrado à vontade formulado para atender às necessidades dos cabritos do nascimento até o desmame (Tabela 2).

Tabela 1 - Composição da ração total consumida pelas cabras durante o período experimental (\%MN)

\begin{tabular}{|c|c|}
\hline Ingrediente & Proporção (\%MN) \\
\hline Silagem de sorgo & 40,00 \\
\hline Milho moído & 13,40 \\
\hline Farelo de soja & 9,00 \\
\hline Casca de soja & 25,50 \\
\hline Polpa cítrica & 9,70 \\
\hline Ureia & 0,60 \\
\hline Suplemento mineral ${ }^{1}$ & 1,80 \\
\hline
\end{tabular}


Tabela 2 - Composição da ração total consumida pelos cabritos do nascimento até o desaleitamento (\%MN)

\begin{tabular}{lc}
\hline Ingrediente & Proporção \\
\cline { 2 - 2 } & $(\% \mathrm{MN})$ \\
\hline Milho moído & 67,30 \\
Farelo de soja & 25,00 \\
Melaço de cana-de-açúcar & 5,20 \\
Calcário & 1,40 \\
Suplemento mineral ${ }^{1}$ & 1,20 \\
\hline${ }^{1}$ Composição química: Ca - 19\%; P -7,5\%; Mg - 1\%; S - 7\%; Cl - 21,8\%; Na - 14,3\%; \\
Mn - 1.100 ppm; Fe - 500 ppm; Zn - 4.600 ppm; Cu - 300 ppm; Co - 405 ppm; \\
I - 80 ppm; Se -15 ppm.
\end{tabular}

As amostras de sangue foram retiradas da veia jugular (aproximadamente $10 \mathrm{~mL}$ ) utilizando-se tubos a vácuo (BD Vacutainer) e o sangue foi centrifugado a $3.500 \mathrm{rpm}$. O soro resultante foi transferido para três frascos devidamente identificados e mantidos a $-20^{\circ} \mathrm{C}$ até serem analisados.

As coletas de sangue das cabras foram iniciadas 45 dias antes da data prevista para o parto, em intervalos de cinco dias, até o 5 o dia após o parto. As datas das coletas para os cabritos foram: 0, 12, 24 e 48 horas, e aos 5, 10, 15, $17,20,25,30,35,40,50$ e 60 dias de vida.

A concentração sérica de proteína total (PT) foi determinada pelo método do biureto (Reinhold, 1953). Por meio de concentrações conhecidas de albumina (Sigma Chemical Company-USA), obtiveram-se as curvaspadrões e, com as leituras das amostras realizadas em espectrofotômetro com comprimento de onda ajustado para $545 \mathrm{~nm}$, foram calculadas as concentrações séricas de proteína total em g/dL.

Na quantificação de imunoglobulinas séricas, foi utilizado o método de turvação por sulfato de zinco (ZST) (McEwan et al., 1970), que se baseia na leitura da turvação obtida da reação das imunoglobulinas, macromoléculas presentes no soro, com o sulfato de zinco. Foram adicionados $100 \mathrm{~mL}$ de soro das amostras a $6 \mathrm{~mL}$ de sulfato de zinco $0,02 \%\left(\mathrm{ZnSO}_{4} \cdot 7 \mathrm{H}_{2} \mathrm{O}\right)$, que foram homogeneizados. Após 60 minutos de incubação, procedeu-se à leitura em espectrofotômetro com comprimento de onda ajustado para $625 \mathrm{~nm}$. As leituras em absorbância foram transformadas em unidades ZST multiplicando-se o valor obtido por 100.

Utilizando o método de imunodifusão radial (IDR) descrito por Mancini et al. (1965), foi estimada a correspondência de unidades ZST, em mg/mL de imunoglobulinas. Para essa estimativa, foram utilizadas amostras séricas de cabritos aleitados com colostro bovino com até 48 horas de vida e o valor encontrado por regressão $\left(\mathrm{r}^{2}=0,72\right.$ e $\mathrm{P}<0,001$ ) foi de $30,98 \mathrm{mg} / \mathrm{mL}$ de IgG para 30 unidades ZST. O método baseia-se na leitura do diâmetro do anel de precipitação formado pela reação do anticorpo da amostra com o anti-IgG bovino em meio ágar, comparando-se com diâmetros de padrões previamente estabelecidos. Para construção da curva-padrão, foram utilizados IgG e antiIgG bovino (Sigma Chemical Company - USA). O ágar empregado foi preparado com concentração de 1,2\% de agarose em tampão TRIS-HCl (pH 8,0) com anti-IgG bovino (Sigma Chemical Company -USA). Além das placas para a curva-padrão, todas as demais usadas com as amostras continham duas concentrações padrão para avaliar variações entre placas. As amostras séricas diluídas (1:10) em TRIS-HCl (pH 8,0) foram homogeneizadas e uma alíquota de $5 \mathrm{~mL}$ foi aplicada, em duplicata, à placa de agarose, as quais foram incubadas em câmara úmida a $4{ }^{\circ} \mathrm{C}$ por 24 horas. As leituras dos diâmetros das reações de precipitação foram medidas em milímetros e as amostras cujas repetições variaram acima de $5 \%$ foram novamente analisadas.

Para quantificação da fração de IgG dos pools de colostro bovino e caprino, foi utilizado o método IDR descrito por Mancini et al. (1965) e modificado por Fleenor \& Stott (1980), no qual as amostras dos pools foram diluídas (1:50) em TRIS-HCl (pH 8,0).

O delineamento experimental utilizado foi inteiramente casualizado e as flutuações nos níveis das variáveis séricas foram analisadas como medidas repetidas. O modelo incluiu os efeitos fixos de tratamento, período e a interação tratamento e período. Para as análises estatísticas, foi utilizado o procedimento PROC MIXED do programa estatístico SAS ${ }^{\circledR}$, versão 8 para Windows ${ }^{\circledR}$ (1999). Para a avaliação de diferenças entre médias, foram feitos contrastes entre pares de médias utilizando-se o método de Tukey. Para todas as análises, considerou-se nível de significância de $5 \%(\mathrm{P}<0,05)$.

Análises de correlação de Pearson utilizando o procedimento PROC CORR do programa estatístico SAS ${ }^{\circledR}$, versão 8 para Windows ${ }^{\circledR}$ (1999), foram realizadas para verificar associações de interesse entre as variáveis séricas.

\section{Resultados e Discussão}

Os valores de proteína total das cabras ao longo do período experimental, com média de 6,34 $\pm 0,73 \mathrm{~g} / \mathrm{dL}$, mantiveram-se nos limites considerados fisiológicos para espécie caprina, como os valores encontrados por Kaneco (1997), que observou concentrações médias de 6,4 a 7,0 g/dL.

As concentrações séricas de proteína total não diferiram durante todo período experimental $(\mathrm{P}=0,8215)$ (Figura 1). As variáveis proteína total e imunoglobulinas séricas foram correlacionadas, com valor de $\mathrm{r}=0,76$, para o período experimental total. Em bovinos, também ocorre elevada correlação entre proteína total e imunoglobulinas 

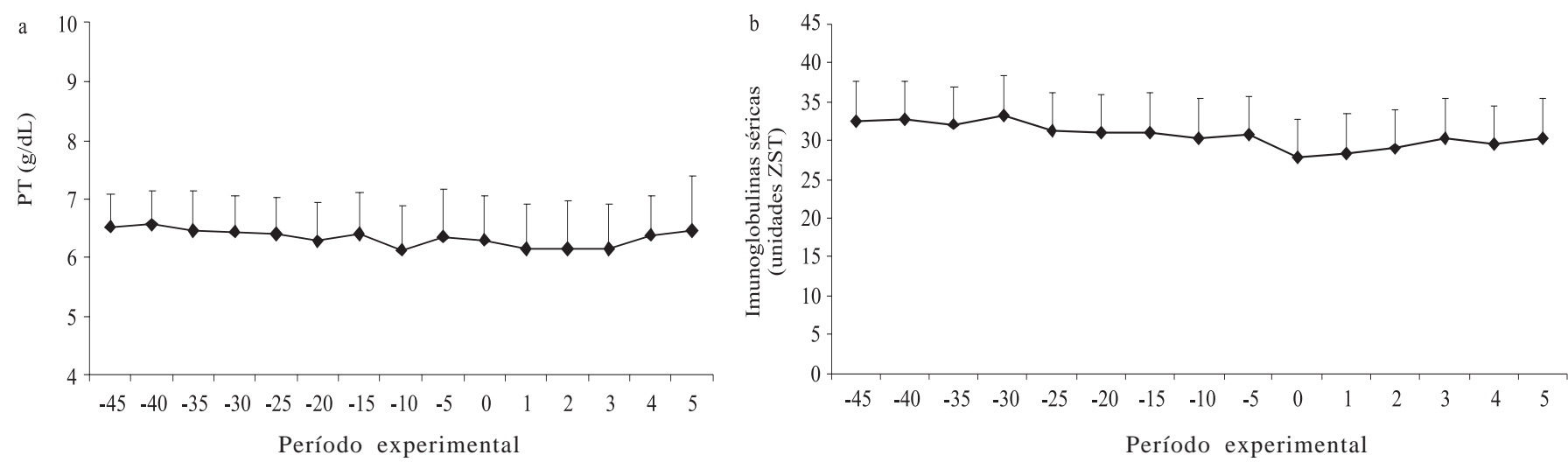

Figura 1 - Flutuação nos níveis de proteína total (a) e imunoglobulinas séricas (b) em cabras ao longo do período experimental.

(Nocek et al., 1984; Machado Neto \& Packer, 1986; Baracat et al., 1997; Pauletti et al., 2002; Pauletti et al., 2005; Kindlein, 2007). Essa interdependência significativa constitui-se importante indicador de coerência metodológica e fisiológica, uma vez que as variáveis foram analisadas por diferentes métodos analíticos e que 20 a $40 \%$ da proteína total é constituída de imunoglobulinas.

A produção de colostro em bovinos leiteiros, em comparação a caprinos, é maior em volume e concentração de imunoglobulinas, o que demanda elevada mobilização de imunoglobulinas da corrente sanguínea para a glândula mamária. A redução na concentração sérica de imunoglobulinas durante o período pré-parto, observada em bovinos, está associada à remoção ativa desses anticorpos pela glândula mamária (Larson \& Kendall, 1957; Sasaki et al., 1976). Em bovinos nas três últimas semanas pré-parto, pesquisadores têm observado mobilização de 500 a 700 g de imunoglobulinas do sangue para a glândula mamária (Dixon et al., 1961; Brandon \& Lascelles, 1971; Foley \& Otterby, 1978).

A manutenção das concentrações séricas de proteína total e imunoglobulinas no período pré-parto indica que a mobilização desses componentes séricos para a glândula mamária ocorre em concentrações que permitem ao animal manter os valores séricos sem variações significativas, embora sejam animais especializados em produção de leite. Essa situação ocorre também em animais com menor produção de secreções lácteas, como vacas da raça Nelore e éguas das raças PSI e Mangalarga (Machado Neto \& d'Arce, 1979; Meo-Scotoni \& Machado Neto, 1992).

As concentrações médias de imunoglobinas no colostro foram $89,34 \pm 19,42$ e $125,74 \pm 12,62 \mathrm{mg} / \mathrm{mL}$ para os colostros caprino e bovino, respectivamente (Tabela 3). Fleenor \& Stott (1980) classificaram colostro bovino com concentrações abaixo de 21,8 mg de imunoglobulinas/mL como de baixo valor imunológico e acima de 49,82 mg/mL como de adequado valor imunológico. Na literatura os valores encontrados para bovinos da raça Holandesa variam de 50 e 120 mg/mL (Burton et al., 1989; Pritchett et al., 1991; Baracat et al., 1997; Tyler et al., 1999; Blum \& Hammon, 2000; Morin et al., 2001; Pauletti et al., 2005). Os valores observados neste trabalho para o colostro caprino se encontram dentro dos limites observados para espécie caprina que variam entre 69,3 a 217,8 mg/mL (Santos et al., 1994).

Os valores médios de proteína total observados nos cabritos, nas primeiras semanas de vida, estão de acordo com os encontrados por O’Brein \& Sherman (1993) e Simões et al. (2005). A concentração de proteína total diferiu $(\mathrm{P}<0,0001)$ entre os grupos e na interação entre grupos e período $(\mathrm{P}<0,0001)$, o que indica diferença de comportamento na flutuação de proteína total entre os grupos ao longo do período experimental.

Nos animais que receberam colostro caprino, não foram observadas diferenças $(\mathrm{P}>0,05)$ nas concentrações após a ingestão, enquanto, naqueles que ingeriram colostro bovino, a concentração máxima de proteína total foi verificada às $48,68 \pm 0,70$ horas de vida e foi seguida de

Tabela 3 - Concentração de IgG nos colostros bovino e caprino

\begin{tabular}{cc}
\hline Colostro bovino & $\begin{array}{c}\text { Concentração de imunoglobinas } \\
(\mathrm{mg} / \mathrm{mL})\end{array}$ \\
\hline 1 & 130,85 \\
2 & 135,01 \\
3 & 111,36 \\
Média \pm desvio-padrão & $125,74 \pm 12,62$ \\
\hline Colostro caprino & Concentração de imunoglobinas \\
& $(\mathrm{mg} / \mathrm{mL})$ \\
\hline 1 & 63,99 \\
2 & 78,82 \\
4 & 118,07 \\
5 & 78,53 \\
6 & 94,46 \\
Média \pm desvio-padrão & 102,19 \\
\end{tabular}


pequena variação até o final do período experimental. As concentrações médias de proteína total às 24 e 48 horas de vida foram de $5,09 \pm 1,18$ e $6,85 \pm 1,11 \mathrm{~g} / \mathrm{dL}$ e $5,21 \pm 1,13$ e $6,95 \pm 1,18 \mathrm{~g} / \mathrm{dL}$ nos grupos que receberam colostro caprino e bovino, respectivamente, enquanto, aos 60 dias de idade, foi $5,77 \pm 0,55 \mathrm{~g} / \mathrm{dL}$.

Halliday (1971) avaliou as concentrações séricas (g/dL) de proteína total de cordeiros das raças Blackface e merino antes da ingestão do colostro e encontraram valores de $4,42 \pm 0,038 ; 4,20 \pm 0,029 ; 4,54 \pm 0,044$ e 4,43 $\pm 0,104$ para os cordeiros provenientes de parto simples e duplo, respectivamente. Neste estudo, no mesmo período, os valores foram de $4,06 \pm 0,66$ e $4,04 \pm 0,65$ para os animais -que receberam os colostros bovino e caprino, respectivamente.

Os valores médios de imunoglobulinas séricas (Figura 2) estão de acordo com aqueles encontrados por Logan (1978), que, trabalhando com o fornecimento de colostro ovino e bovino para cordeiros recém-nascidos imediatamente após o nascimento encontrou para os animais que receberam $250 \mathrm{~mL}$ concentração média de imunoglobulinas séricas de 14 e 13,25 unidades ZST para colostro ovino e bovino, respectivamente. Quando fornecido $500 \mathrm{~mL}$ de colostro, no entanto, observou-se concentração média de 32 e 37 unidades ZST para os animais que receberam colostros ovino e bovino, respectivamente. As imunoglobulinas heterólogas do colostro bovino foram absorvidas com a mesma eficiência das imunoglobulinas homólogas do colostro ovino, fato que está diretamente relacionado à homologia das moléculas.

Assim como observado no trabalho de Logan (1978), neste estudo, o uso de colostro bovino em substituição ao caprino, fonte heteróloga de anticorpos, mostrou-se um meio exequível e eficiente para proporcionar níveis adequados de proteção passiva inicial.

A concentração de imunoglobulinas diferiu $(\mathrm{P}=0,0006)$ entre os grupos e na interação entre grupos e período $(\mathrm{P}<0,0001)$, o que indica diferença na flutuação de imunoglobulinas séricas entre os grupos ao longo do período experimental. Por ocasião do nascimento, os cabritos apresentam-se agamaglobulinêmicos ou hipogamaglobulinêmicos, com valor médio de 2,92 $\pm 0,45$. As concentrações médias de imunoglobulinas às 24 e 48 horas de vida foram 18,27 \pm 7,38 e 35,27 \pm 10,42 unidades ZST e 20,80 \pm 7,38 e 37,27 $\pm 10,40$ unidades ZST para os grupos que receberam colostro caprino e colostro bovino, respectivamente. Essa diferença entre os grupos foi observada até 25 dias de vida e, no período, as médias foram de 18,26 $\pm 5,50$ unidades ZST para os animais que receberam colostro caprino e de 27,59 \pm 8,94 unidades ZST para os que receberam colostro bovino.

Nos cabritos que receberam colostro bovino (grupo B) a concentração máxima de proteína total foi verificada às $48,68 \pm 0,70$ horas dia de vida $(7,16 \pm 0,28 \mathrm{~g} / \mathrm{dL})$ e a concentração máxima de imunoglobulinas foi verificada às 48,75 $\pm 0,73$ horas de vida $(37,56 \pm 2,38$ unidades ZST), situação que evidencia a interdependência das duas variáveis. Em seguida os valores decresceram gradativamente, em virtude do catabolismo das imunoglobulinas adquiridas passivamente, condição também observada em bovinos por Klaus et al. (1969); Husband et al. (1972); Logan et al. (1978); Machado Neto \& Packer (1986) e Pauletti et al. (2002).
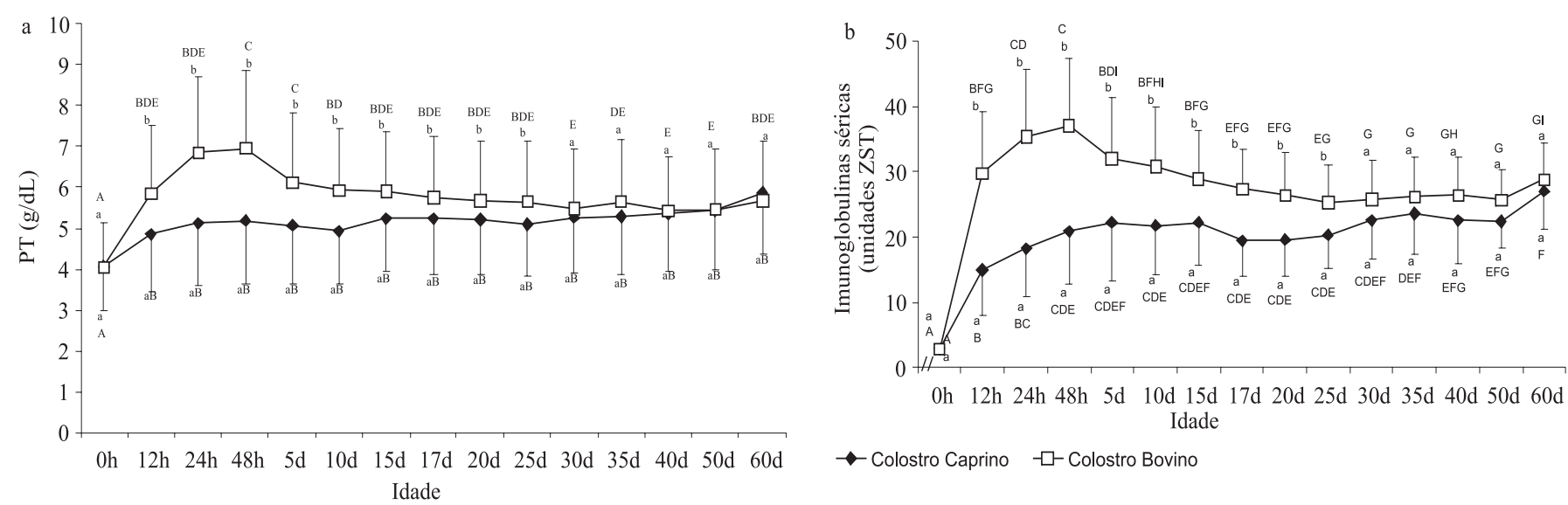

ABCDEFGHI Médias seguidas de letras diferentes, dentro de cada grupo, diferem $(\mathrm{P}<0,05)$ pelo teste de Tukey.

${ }^{\text {ab }}$ Médias seguidas de letras diferentes, dentro do mesmo período, diferem $(\mathrm{P}<0,05)$ pelo teste de Tukey.

Figura 2 - Flutuação da concentração média de proteína total (a) e imunoglobulinas séricas (b) em cabritos recém-nascidos recebendo colostros bovino e caprino. 
Nos cabritos que receberam colostro caprino (grupo A), a concentração máxima das variáveis séricas proteína total e imunoglobulinas ocorreram mais tardiamente aos 17,94 $\pm 1,39$ e 20,11 $\pm 1,17$ dias de vida, e as médias foram de $5,91 \pm 0,22 \mathrm{~g} / \mathrm{dL}$ e 28,17 $\pm 2,29$ unidades ZST, respectivamente.

No final do período experimental, aos 60 dias de vida, os valores para proteína total foram de 5,86 $\pm 0,36$ e 5,67 \pm 0,58 g/dL e para imunoglobulinas e 27,11 $\pm 5,84$ e 28,66 $\pm 5,70$ unidades ZST nos grupos A e B, respectivamente.

O coeficiente de correlação significativo entre proteína total e imunoglobulinas séricas para todo período experimental igual a $r=0,68$ confirma o padrão de variação semelhante e interdependente das duas variáveis.

A flutuação sérica de imunoglobulinas revela que o colostro bovino é superior quanto ao uso proteína total. No grupo que recebeu colostro bovino, apesar das maiores variações ao longo do período experimental, os animais mantiveram concentrações séricas superiores às observadas no grupo que recebeu colostro caprino até os 25 dias de vida, pois as concentrações superiores de imunoglobulinas no colostro bovino refletem em maiores concentrações séricas nos recém-nascidos, o que comprova a possibilidade de substituição do colostro caprino por colostro bovino.

\section{Conclusões}

O processo de formação do colostro em cabras com níveis adequados de anticorpos não interfere na flutuação dos níveis séricos de proteína total e imunoglobulinas. O colostro bovino pode ser utilizado como alternativa de fonte de anticorpos para cabritos recém-nascidos e é mais eficiente em conferir condição inicial de anticorpos séricos aos cabritos neonatos. O padrão básico do comportamento das concentrações séricas de proteína total e imunoglobulinas em caprinos é o mesmo de animais que dependem de anticorpos maternos para aquisição da imunidade inicial.

\section{Agradecimentos}

À Fundação de Amparo à Pesquisa do Estado de São Paulo (Fapesp) e ao Conselho Nacional de Desenvolvimento Científico e Tecnológico (CNPq), pelo apoio ao desenvolvimento desta pesquisa.

\section{Literatura Citada}

ARGÜEllo, A.; CAStro, N.; CAPOTE, J. et al. Effects of refrigeration, freezing-thawing and pasteurization on IgG goat colostrum preservation. Small Ruminant Research, v.48, n.2, p.135-139, 2003
BARACAT, R.S.; MACHADO NETO, R.; DANIELE, C. et al. Fornecimento prolongado de colostro e proteção passiva em bezerros recém-nascidos. Pesquisa Agropecuária Brasileira, v.32, n.11, p.215-220, 1997.

BLUM, J.W.; HAMMON, H. Colostrum effects on the gastrointestinal tract, and on, nutritional, endocrine and metabolic parameters in neonatal calves. Livestock Production Science, v.66, n.2, p.151-159, 2000.

BRANDON, M.R.; LASCELLES, A.K. Relative efficiency of absorption of $\operatorname{IgG}_{1}, \operatorname{IgG}_{2}$, IgA and IgM in the newborn calves. Australian Journal of Experimental Biology and Medical Science, v.49, n.6, p.629-633, 1971.

BURTON, J.L.; KENNEDY, B.W.; BURNSIDE, B.N. et al. Variation in serum concentrations of immunoglobulins $G$, $A$ and $M$ in Canadian Holstein-Friesian calves. Journal of Dairy Science, v.72, n.1, p.135-149, 1989.

CORK, L.C.; HADLOLOW, W.J.; CRAWFORD, T.B. Infectious leukoencephalomyelitis of young goats. Journal Infectious Disease, v.129, n.2, p.134-141, 1974.

CRAWFORD, T.B.; ADAMS, D.S. Caprine arthritis-encephalitis: clinical features and presence of antibody in selected goat populations. Journal American Veterinary Medical Association, v.178, n.7, p.713-719, 1981.

DIXON, F.J.; WEIGLE, W.O.; VAZQUEZ, J.J. Metabolism and mammary secretion of serum proteins in the cow. Laboratory Investigation, v.10, n.2, p.216-236, 1961.

FLEENOR, W.A.; STOTT, G.H. Hydrometer test for estimation of immunoglobulin concentration in bovine colostrum. Journal of Dairy Science, v.63, n.6, p.973-977, 1980.

FOLEY, J.A.; OTTERBY, D.E. Availability, storage, treatment, composition and feeding value of surplus colostrum: A review. Journal Dairy Science, v.61, n.8, p.1033-1060, 1978.

HALLIDAY, R. Total serum protein and immunoglobulin concentration in Scottish Blackface and Merino lambs at birth and during the first two days of sucking. Journal of Agricultural Sciences, v.77, n.3, p.463-466, 1971.

HALLIDAY, R. Variation in immunoglobulin transfer from ewes to lambs. Annales de Recherches Veterinaires, v.23, n.2, p.425-427, 1978.

HUSBAND, A.J.; BRANDON, M.R.; LASCELLES, A.K. Absorption and endogenous production of immunoglobulins in calves. Australian Journal of Experimental Biology and Medical Science, v.50, n.4, p.491-498, 1972.

KANEKO, J.J. Serum proteins and the dysproteinemias. In: KANEKO, J.J.; HARVEY, J.W.; BRUSS, M.L. Clinical biochemistry of domestic animals. 5.ed. London: Academic Press, 1997. cap.5. p.117-138.

KINDLEIN, L.; PAULETTI, P.; BAGALDO, A.R. et al. Efeito do fornecimento adicional de colostro sobre as concentrações séricas de IgG, PT e IGF-I de bezerros neonatos. Revista Brasileira de Saúde e Produção Animal, v.8, p.375-385, 2007.

KLAUS, G.G.B.; BENNET, A.; JONES, E.W. A quantitative study of the transfer of colostral immunoglobulins to the newborn calf. Immunology, v.16, n.3, p.293-299, 1969.

LARSON, B.L.; KENDALL, K.A. Changes in specific blood serum protein levels associated parturition in the bovine. Journal of Dairy Science, v.40, n.6, p.659-667, 1957.

LOGAN, E.F. A note on bovine colostrums as an alternative source of immunoglobulin for lambs. Animal Production, v.26, n.1, p.93-96, 1978.

LOGAN, E.F.; McMURRAY, C.H.; O'NEILL, D.G. et al. Absorption of colostral immunoglobulins by the neonatal calf. British Veterinary Journal, v.134, n.3, p.258-262, 1978.

MACHADO NETO, R.; d'ARCE, R.D. Gamaglobulinas séricas de bezerros recém-nascidos da raça Nelore. Revista da Agricultura, v.53, p.13-19, 1979.

MACHADO NETO, R.; PACKER, I.U. Flutuação de imunoglobulina sérica em bezerros da raça Holandesa submetidos a diferentes 
regimes de aleitamento. Revista Brasileira de Zootecnia, v.15, n.5, p.439-447, 1986.

MANCINI, G.; CARBONARA, A.O.; HERMANS, J.E. Immunochemical quantification of antigens by single radial immunodifusion. Immunochemistry, v.2, n.3, p.235-254, 1965.

McEWAN, A.D.; FISHER, E.W.; SELMAN, I.E. A turbity test for the estimation of immunoglobulin levels in neonatal calf serum. Clinical Chemical Acta, v.27, n.1, p.155-163, 1970.

MEO-SCOTONI, C.M.; MACHADO NETO, R. Transferência de imunidade passiva em eqüinos: características imunológicas do processo de formação do colostro. Revista Brasileira de Zootecnia, v.21, n.2, p.200-204, 1992.

MORIN, D.E.; CONSTABLE, P.D.; MAUNSELL, F.P. Factors associated with colostral specific gravity in dairy cows. Journal of Dairy Science, v.84, n.4, p-937 943, 2001.

NOCEK, J.E.; BRAUND, D.G.; WARNER, R.G. Influence of neonatal colostrum administration, immunoglobulin, and continued feeding of colostrum on calf gain, health and serum protein. Journal of Dairy Science, v.67, n.2, p.319-333, 1984.

O'BREIN, J.P.; SHERMAN, D.M. Serum immunoglobulin concentrations of newborn goat kids and subsequent kid survival through weaning. Small Ruminant Research, v.22, n.3, p.299-305, 1993.

PAUletti, P.; MACHAdO NETO, R.; PACKER, I.U. et al. Avaliação de níveis séricos de imunoglobulina, proteína e o desempenho de bezerras da raça Holandesa. Pesquisa Agropecuária Brasileira, v.37, n.1, p.89-94, 2002.

PAULETTI, P.; BALGADO, A.R.; KINDLEIN, L. et al. IGF-I e IgG séricos e nas secreções lácteas em vacas tratadas com rbST no período pré-parto. Revista Brasileira de Zootecnia, v.34, n.3, p.976-986, 2005.

PRITCHETT, L.C.; GAY, C.C.; BESSER, T.E. et al. Management and production factors influencing immunoglobulin $G_{1}$ concentration in colostrum from Holstein cows. Journal of Dairy Science, v.74, n.7, p.2336-2341, 1991.

REINHOLD, J.G. Total protein, albumin and globulin. In: REINER, M. Standard Methods of Clinical Chemistry. New York: Academic Press, 1953. v.1, p.88.

SANTOS, T.G.; BERTOLINI, D.A.; MACEDO, F.A.F. et al. Variabilidade em imunoglobulina G (IgG) no colostro de cabra de primeira ordenha e absorção intestinal de IgG pelos cabritos recém-nascidos. Brazilian Archives of Biology and Technology, v.37, n.2, p.285-292, 1994.

SASAKI, M.; DAVIS, C.L.; LARSON, B.L. Production and turnover of $I_{g G_{1}}$ e $I_{g G_{2}}$ immunoglobulins in the bovine around parturition. Journal of Dairy Science, v.59, n.12, p.20462055, 1976.

SIMÕES, S.V.D.; COSTA, R.G.; SOUZA, P.M. et al. Imunidade passiva, morbidade neonatal e desempenho de cabritos em diferentes manejos de colostro. Pesquisa Veterinária Brasileira, v.25, n.4, p.219-224, 2005.

STATISTICAL ANALYSIS SYSTEM - SAS. SAS: user's guide statistic. 6.ed. Cary: 1999. 956p.

TYLER, J.W.; STEEVENS, B.J.; HOSTELER, D.E. et al. Colostral immunoglobulin concentrations in Holstein and Guernsey cows. American Journal of Veterinary Research, v.60, n.9, p.1136-1139, 1999. 